
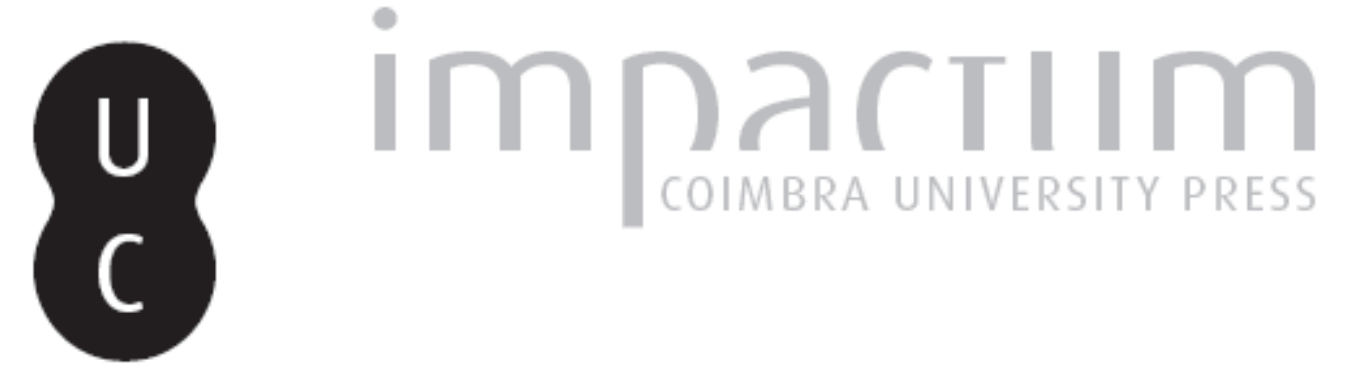

\title{
O ensino da História Medieval Europeia na Faculdade de Letras de Coimbra (1941- 2011) e no Portugal de hoje
}

\author{
Autor(es): $\quad$ Monteiro, João Gouveia
}
Publicado por: Faculdade de Letras da Universidade de Coimbra, Institituto de História Económica e Social

URL persistente:

URl:http://hdl.handle.net/10316.2/28005

DOI:

DOI:http://dx.doi.org/10.14195/0870-4147_42_14

Accessed : $\quad$ 26-Apr-2023 08:44:02

A navegação consulta e descarregamento dos títulos inseridos nas Bibliotecas Digitais UC Digitalis, UC Pombalina e UC Impactum, pressupõem a aceitação plena e sem reservas dos Termos e Condições de Uso destas Bibliotecas Digitais, disponíveis em https://digitalis.uc.pt/pt-pt/termos.

Conforme exposto nos referidos Termos e Condições de Uso, o descarregamento de títulos de acesso restrito requer uma licença válida de autorização devendo o utilizador aceder ao(s) documento(s) a partir de um endereço de IP da instituição detentora da supramencionada licença.

Ao utilizador é apenas permitido o descarregamento para uso pessoal, pelo que o emprego do(s) título(s) descarregado(s) para outro fim, designadamente comercial, carece de autorização do respetivo autor ou editor da obra.

Na medida em que todas as obras da UC Digitalis se encontram protegidas pelo Código do Direito de Autor e Direitos Conexos e demais legislação aplicável, toda a cópia, parcial ou total, deste documento, nos casos em que é legalmente admitida, deverá conter ou fazer-se acompanhar por este aviso.

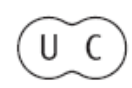





\title{
O Ensino da História Medieval Europeia na Faculdade de Letras de Coimbra (1941-2011) e no Portugal de hoje*
}

\author{
JoÃo Gouveia MonTeIro \\ Faculdade de Letras da Universidade de Coimbra \\ Centro de História da Sociedade e da Cultura - FLUC \\ jgmonteiro@mail.telepac.pt
}

Resumo:

Pretende-se neste artigo alcançar dois objectivos. Por um lado, evocar os Mestres da 'escola de Coimbra' que se dedicaram ao ensino da história medieval europeia nesta Faculdade de Letras a partir de 1941. Ou seja, a partir do magistério do fundador desta revista, o Doutor Torquato de Sousa Soares. Quisemos lembrar os programas desses Mestres e perceber quais os temas que mais mereceram a sua atenção. Por outro lado, procede-se a um breve levantamento do que é hoje, na era pós-Bolonha, o ensino da história geral da Idade Média nas principais universidades portuguesas. Sobretudo com o objectivo de informar e de fornecer termos de comparação, facilitando qualquer debate ou reflexão crítica que, em conjunto, se queira vir a fazer a este respeito.

Palavras chave:

Ensino da História; Idade Média; Universidade de Coimbra.
Abstract:

With this article we try to reach two goals: on one hand, to remember the Masters of the 'school of Coimbra' who devoted themselves to the teaching of European Medieval History from 1941 on, that is to say, beginning with Torquato de Sousa Soares, the founder of this journal. Our wish was to recall their syllabuses and thus understand which subject matters deserved their special attention. On the other hand, we conducted a general survey of what is today, in this period after the Bologna Declaration, the teaching of Medieval History in the main Portuguese universities. Our purpose was to inform and provide terms of comparison, thus easing any comprehensive discussion or critical reflection on this matter that might be undertaken together.

Keywords:

History teaching; Middle Ages; University of Coimbra.

* Este artigo retoma, actualiza e desenvolve substancialmente a parte inicial do Relatório da disciplina de "História da Idade Média II" apresentado no âmbito das Provas de Agregação prestadas na Faculdade de Letras da Universidade de Coimbra em Novembro de 2005 (prova de que foi arguente o Senhor Doutor Armando Luís de Carvalho Homem). 


\section{Enquadramento curricular}

O ensino da História da Idade Média europeia integrou sempre, de uma maneira ou de outra, os planos curriculares da Faculdade de Letras da Universidade de Coimbra [FLUC], à maneira, decerto, do que se verificou nas restantes universidades portuguesas. Vale a pena, no entanto, observar o enquadramento a que ele foi estando sujeito ao longo dos últimos 70 anos.

Uma consulta dos sumários depositados no Arquivo da Universidade de Coimbra e na própria FLUC, cobrindo o período compreendido entre os anos lectivos de 1941-42 e 2010-2011, permitiu-nos reconhecer a existência de sete etapas principais ${ }^{1}$ :

- entre 1941-42 e 1957-58, o ensino da época medieval, numa perspectiva europeia, era assegurado na disciplina de "História Medieval", leccionada, na esmagadora maioria daqueles anos lectivos, pelo Senhor Doutor Torquato de Sousa Soares ${ }^{2}$.

- a partir de 1958-59, a disciplina passou a chamar-se "História da Idade Média", designação que manteria até à revolução de 1974. Figurava então no 2..$^{\circ}$ ano do curso de História, a par das disciplinas de "História Medieval de Portugal" (leccionada pelo Doutor Torquato S. Soares) e de "História da Cultura Medieval" (geralmente a cargo do Doutor José Maria da Cruz Pontes). Durante esses anos, a "História da Idade Média"continuou a ser sobretudo leccionada pelo Doutor Torquato de Sousa Soares, que viria a jubilar-se durante o ano lectivo de 1972-73, entregando então

1 Esta consulta tornou-se ainda mais fácil por cortesia da então Directora do Arquivo da Universidade de Coimbra, Senhora Doutora Maria José Azevedo Santos, a quem coube também o mérito de organizar primorosamente esses materiais. A escolha do arco cronológico 1941-2011 deveu-se à necessidade de abarcar um período vasto, de modo a este estudo ser suficientemente representativo, sem contudo se tornar inexequível ou demasiado disperso. O ano lectivo de 1941-42 marca ainda o início do magistério do curso de história medieval pelo Doutor Torquato de Sousa Soares, que é sem dúvida uma referência da "Escola de Coimbra".

2 O Doutor Torquato de Sousa Soares substituiu o Doutor Mário Brandão na regência da "História Medieval" a meio do ano lectivo de 1941-42, assegurando, a partir de então, as aulas desta disciplina, até 1955-56. No ano seguinte (1956-57), foi a vez de o Doutor Torquato ser substituído, a meio do ano lectivo, pelo Doutor Mário Brandão. No ano subsequente (1957-58), a leccionação das aulas de "História Medieval" foi assegurada pelo Doutor Luís Ferrand de Almeida. Convém ainda recordar que, pelo menos entre os anos lectivos de 1951-52 e 1956-57, coube ao Senhor Doutor Cónego Avelino de Jesus da Costa assegurar as aulas práticas de "História Medieval". Ressalve-se que não se encontra disponível o livro de sumários relativo ao ano de 1952-53. 
o testemunho desta disciplina nuclear à Senhora Doutora Maria Helena da Cruz Coelho ${ }^{3}$.

- com a ocorrência do 25 de Abril de 1974, os esquemas curriculares foram natural e profundamente alterados. Um plenário do curso de História realizado em 11 de Outubro de 1974 aprovaria um novo plano de estudos, tacitamente ratificado pelo Governo por via do Decreto-Lei 806/74, de 31 de Dezembro, onde se conferiam à Assembleia de Escola os poderes necessários à definição dos princípios gerais a que deveriam obedecer as actividades científicas e pedagógicas da Faculdade. Nestes termos, o ensino da História da Idade Média europeia passou a ser ministrado em duas novas e muito vanguardistas (pelo menos nas suas designações) cadeiras: "História das Sociedades Feudais" (disciplina obrigatória do 2. ano do curso de História) e "História do Pré-Capitalismo e do Capitalismo Comercial" (disciplina obrigatória do $3 .^{\circ}$ ano do mesmo curso) ${ }^{4}$. Deve ainda dizer-se que esta reforma pensava a estrutura do curso de História em dois ciclos (três anos para o bacharelato e mais dois para uma pré-especialização em área cronológica à escolha do aluno) e não previa qualquer disciplina específica de História de Portugal no âmbito do bacharelato, devendo por isso os docentes assegurar, nessa fase, a orientação dos temas principais da história portuguesa no contexto

3 Sem prejuízo disso, deve acrescentar-se que, no ano lectivo de 1958-59 (o ano da estreia da nova designação), coube ao Doutor Luís Ferrand de Almeida assegurar as aulas até ao mês de Janeiro. Da mesma forma, nos anos lectivos de 1968-69 e 1969-70 foi o Doutor Avelino de Jesus da Costa quem assegurou as aulas (teóricas e práticas) de "História da Idade Média". Infelizmente, não dispomos de informação relativa aos anos de 1964-65, 1965-66, 1966-67 e 1967-68. A transição, em 1972-73 (supomos que no mês de Março), da regência de "História da Idade Média", das mãos do Doutor Torquato de Sousa Soares para as da Doutora Maria Helena da Cruz Coelho há-de ter-se feito de uma forma bastante natural, uma vez que esta docente vinha já assegurando as respectivas aulas práticas. Por ocasião da "revolução dos cravos", era portanto a Doutora Maria Helena Coelho quem se encontrava já ao leme da "História da Idade Média".

4 Tendo entrado como estudante na FLUC em Outubro de 1976, tivemos a oportunidade de frequentar (em 1977-78 e em 1978-79) essas duas disciplinas, na altura leccionadas pelas Senhoras Doutoras Maria José Azevedo Santos (2. ${ }^{\circ}$ ano) e Maria Teresa Nobre Veloso (3..$^{\circ}$ ano) e com uma carga horária de apenas uma aula de duas horas por semana. Como os próprios nomes indicam, a "História das Sociedades Feudais" era uma disciplina vocacionada para uma cronologia mais recuada (da crise do Império Romano do Ocidente ao triunfo do modo de produção feudal), enquanto à "História do Pré-Capitalismo e do Capitalismo Comercial" cabia sobretudo desenhar os grandes quadros da história europeia dos séculos XII a XV. 
das cadeiras de história geral europeia que leccionavam ${ }^{5}$. Mais tarde, nos últimos dois anos, sim, a História do Portugal medieval (ou moderno, ou contemporâneo, tudo dependia da escolha do aluno) poderiam aparecer em força, e até em condições muito gratificantes de ensino e de aprendizagem, sobretudo no caso da época medieval (menos procurada devido às exigências específicas da sua investigação em matéria de conhecimentos paleográficos e de domínio da língua latina, e, por isso, mais facilmente valorizada em termos de contacto de pequenos grupos de alunos com a documentação e com as regras essenciais da investigação). - o "modelo de Abril" funcionaria, no entanto, por pouco tempo, pois em 1978 , por via do Decreto-Lei n ${ }^{\circ} 53 / 78$, uma nova reforma curricular do curso de História entrava em vigor e desta feita em simultâneo em todas as universidades portuguesas. $\mathrm{O}$ curso de História era reduzido para quatro anos, com um total de 21 disciplinas (cada qual com duas aulas de duas horas por semana), e o ensino da história europeia era de novo separado do da história portuguesa (objecto agora de uma disciplina autónoma em cada ano do curso) e, sobretudo, via-se subdividido em três áreas distintas (mas todas elas obrigatórias para os alunos do curso de História): História Económica e Social, História Institucional e Política e História Cultural e das Mentalidades. No 2. ${ }^{\circ}$ ano do curso, onde tradicionalmente se ensinava a Idade Média, a cronologia de cada uma destas cadeiras era fixada entre os séculos III e XIV ${ }^{6}$.

- a reforma de 1978, por um lado, garantia um tratamento 'de luxo' ao ensino da história europeia da Idade Média (como ao das outras épocas, que contudo não interessam ao nosso caso), reservando-lhe três cadeiras

5 Assim, e a título de exemplo, a "revolução" portuguesa de 1383-85 era abordada pela Senhora Doutora Teresa Veloso no âmbito da disciplina de "História do Pré-Capitalismo e do Capitalismo Comercial", a par das suas congéneres europeias de finais do século XIV.

6 Tendo sido contratado pela FLUC, como Assistente Estagiário, em Outubro de 1982, tivemos a oportunidade de leccionar vários anos a disciplina de "História Cultural e das Mentalidades (sécs. III-XIV)", primeiro em colaboração com o nosso colega Doutor António Resende de Oliveira (assegurando as aulas práticas) e, mais tarde, sozinhos. Paralelamente, o ensino das disciplinas de "História Económica e Social (sécs. III-XIV)" e de "História Institucional e Política (sécs. III-XIV)" era assegurado por outros colegas, como os Senhores Doutores Maria Teresa Veloso e João Cunha Matos (no primeiro caso) e José Antunes (no segundo caso, devendo ainda dizer-se que, no ano lectivo de 1979-80, a regência da "História Institucional e Política (sécs. III-XIV)" pôde contar com a colaboração do Senhor Doutor José Mattoso). Refira-se também que os alunos da variante de Arqueologia, se eram obrigados, em cada ano, a fazer a cadeira de História Cultural e das Mentalidades, podiam no entanto optar entre as outras duas (História Económica e Social ou História Institucional e Política). 
anuais obrigatórias e permitindo com isso o aprofundamento de uma grande quantidade de temas; mas, por outro lado, não deixava de causar algumas dificuldades: era muitas vezes difícil permanecer acantonado em cada uma das ditas três áreas, sem a tentação (e frequentemente a necessidade) de 'namorar' a disciplina vizinha, um problema que se agravava dada a tradicional dificuldade dos docentes universitários em coordenar uns com os outros o ensino ministrado nas suas várias cadeiras, tanto do ponto de vista cronológico como temático. Assim, surgiu em 1986 uma nova reforma do curso de História de Coimbra, introduzida pela Portaria n. ${ }^{\circ}$ 508/86. O curso mantinha a duração de quatro anos, mas as três cadeiras de história europeia por cada ano lectivo desapareciam, fundindo-se numa única (obrigatória para o curso de História e para as variantes de História da Arte e Arqueologia) que, no caso do 2. ${ }^{\circ}$ ano, (re)adquiria a designação de ... "História da Idade Média". Regressava-se, assim, à nomenclatura de 1958-59, embora num enquadramento curricular notoriamente diverso 7 . $\mathrm{O}$ ensino da história medieval europeia recuperava, assim, alguma da unidade que perdera, sem prejuízo de as preferências científicas dos docentes 'inclinarem' a respectiva abordagem num sentido mais próximo da história económica e social, ou da história política e das instituições, ou da história cultural e mental. Essa era, de resto, uma situação assumida por todos e cabia expressamente aos alunos, no acto de inscrição nas turmas no início de cada ano lectivo, optar pelo programa que mais os aliciava, ou que melhor correspondia aos seus projectos científicos e profissionais. Manda, no entanto, a verdade que se diga que esta nova reforma obrigou os docentes a um enorme esforço de síntese para garantir a idoneidade da

7 Curiosamente, as principais universidades portuguesas revelaram, nesta altura, entendimentos assaz distintos quanto à melhor solução a implementar nos seus cursos de História. Se no Porto se optou por uma 'fusão mitigada' (as três disciplinas de história europeia da etapa precedente dando origem a duas: "Sociedade, Economia e Política" e "Cultura e Mentalidades": cf. Portaria n. $.^{\circ} 850 / 87$, de 3 de Novembro), em Lisboa oscilou-se entre a conservação total do modelo vindo de trás (Faculdade de Ciências Sociais e Humanas da Universidade Nova de Lisboa: cf. Portaria n. $.^{\circ} 853 / 87$, de 4 de Novembro) e a solução adoptada na Faculdade de Letras da Universidade de Lisboa, que em matéria de história europeia aceitava (como Coimbra) a redução a uma única cadeira de história geral por ano curricular, mas que desdobrava a História de Portugal em duas disciplinas, uma de "Política, Sociedade e Economia" e outra de "Cultura e Mentalidades" (cf. Portaria n. ${ }^{\circ}$ 852/87, de 4 de Novembro). Na Universidade de Coimbra, tivemos durante muitos anos (em boa verdade até 2003-2004, apenas com algumas interrupções) o gosto de dividir a regência desta cadeira de "História da Idade Média" com as nossas colegas Doutoras Maria Teresa Nobre Veloso, Maria Rosa Ferreira Marreiros e (de forma mais pontual) Maria Antónia Lopes. 
formação científica dos seus alunos à entrada do ano lectivo seguinte (onde até poderiam não ter nenhum docente que prolongasse de maneira natural o programa do ano anterior, caso este tivesse sido demasiado construído sobre uma só das vertentes da História). No fundo, em termos ideais, tratava-se de leccionar, numa só cadeira (com duas aulas de duas horas por semana), ao menos aquilo que de mais importante era ensinado, até então, em três disciplinas diferentes, cada qual com a mesma carga horária...

- uma sexta etapa correspondeu à introdução de um novo plano curricular no conjunto da FLUC, no ano lectivo de 2003-2004. Desta reforma, que preservou a identidade e a designação da "História da Idade Média", destaco sobretudo a passagem ao regime semestral, o que provocou o desdobramento daquela disciplina em duas: "História da Idade Média I" e "História da Idade Média II". Os limites cronológicos de cada uma destas cadeiras não foram estabelecidos à partida, cabendo aos respectivos docentes fixá-los da forma mais pertinente possível ${ }^{8}$. Simultaneamente, a carga horária por disciplina foi reduzida para três horas semanais, divididas em duas aulas de uma hora e meia cada ${ }^{9}$. Frisamos ainda que, no âmbito desta reforma, as variantes de História da Arte e de Arqueologia se constituíram como licenciaturas autónomas, intituladas "História da Arte" e "Arqueologia e História" e de cujos elencos curriculares não constavam as disciplinas de "História da Idade Média I" e "História da Idade Média II", que assim se destinavam exclusivamente aos alunos da licenciatura em História ${ }^{10}$.

- uma sétima e derradeira etapa resultou da entrada em vigor, em 2007-2008, de um novo plano de estudos, na sequência da implementação da chamada "reforma de Bolonha". Teríamos muito para dizer acerca desta reforma

8 Entretanto, a tendência foi para separar os dois semestres no século XI (um pouco mais aquém, ou um pouco mais além, consoante as próprias matérias eleitas como prioritárias).

9 Por tradição, tem competido aos docentes determinar, ano a ano, a distribuição do tempo de aula teórica e de aula prática. Assim, enquanto alguns optam por separar claramente as aulas teóricas das práticas, realizando uma aula de cada tipo por semana, já outros (porventura a maioria) preferem adoptar o modelo, mais flexível, das aulas teórico-práticas, realizando um pouco de cada tarefa em cada sessão.

${ }^{10}$ Entretanto, os alunos da licenciatura em História da Arte deviam frequentar, em princípio no 3. ${ }^{\circ}$ semestre, a disciplina de "História Medieval" (uma história da Idade Média europeia duplamente sintetizada e adaptada às exigências dos formandos em História da Arte, por isso especialmente atenta aos aspectos sociais, religiosos e culturais) e, no semestre seguinte, a cadeira de "História Medieval de Portugal". Pelo seu lado, aos alunos da licenciatura em "Arqueologia e História" era proposto que frequentassem a disciplina de "História Medieval" no 5. semestre do seu curso e a de "História Medieval de Portugal" no semestre seguinte. 
europeia, mas não queremos perder de vista o objectivo do nosso trabalho e o aspecto mais importante a focar aqui é a divisão do ensino da história medieval europeia em duas cadeiras semestrais, intituladas "História da Idade Média" e "Temas de História Medieval". Dir-se-á que a diferença não é grande relativamente ao modelo imediatamente anterior. Porém, em teoria, o espírito é algo distinto: na "História da Idade Média" prevê-se que o docente trace uma visão panorâmica do conjunto da história medieval, cabendo à disciplina do 2. . $^{\circ}$ emestre ("Temas de História Medieval") aprofundar alguns temas seleccionados pelo docente em resultado da sua relevância e representatividade. Ou seja, a separação entre as duas disciplinas pode não ser cronológica, como na reforma anterior, mas pressupor antes uma organização completamente diferente das matérias, em especial no que diz respeito aos "Temas de História Medieval". Além disso, ambas as disciplinas são agora propostas a alunos do $1 .^{\circ}$ ano, o que tem implicações muito significativas ao nível do ensino: ritmo (e ambiente) das aulas, organização dos materiais de apoio (sobretudo da bibliografia), natureza dos trabalhos práticos de consolidação da aprendizagem, etc. Por fim, os estudantes da nova licenciatura em História e Geografia e Geografia e História têm também no seu curriculum (no 2. semestre) a disciplina de "História da Idade Média", circunstância que, em princípio, convidaria a uma escolha de matérias e a uma abordagem um pouco diferenciadas, caso eles não partilhassem as aulas desta disciplina com as lições de "Temas de História Medieval” dos seus colegas de História ${ }^{11} \ldots$

\section{Conteúdos programáticos}

Se esta incursão pela evolução dos planos de estudo se revelou curiosa, mais interessante ainda (e mais instrutiva para o nosso propósito) se mostra a análise dos programas desenvolvidos pelos docentes que asseguraram o ensino da história medieval europeia na FLUC durante o mesmo período (1941-2011). Afinal, que matérias escolheram, em concreto, os mestres da "Escola

${ }^{11}$ Quer as disciplinas da reforma de 2003-2004 ("História da Idade Média I" e "História da Idade Média II"), quer as da reforma de Bolonha, actualmente em vigor ("História da Idade Média" e "Temas de História Medieval"), tiveram e têm como principal docente na FLUC a Senhora Doutora Maria Teresa Veloso, tendo eu próprio tido o gosto de a acompanhar (com intermitências várias) ao longo destes anos. 
de Coimbra" responsáveis pelo ensino da história geral da Idade Média, ao longo das últimas sete décadas?

Regressemos a 1942-43. Entre esta data e o ano lectivo de 1971-72, inclusive, dispomos de 20 livros de sumários de "História Medieval" (ou de, a partir de 1958-59, "História da Idade Média") assinados pelo Doutor Torquato de Sousa Soares, em regime de leccionação exclusiva da cadeira. É um universo generoso e que permite conclusões seguras. Em cada ano lectivo, numa média de 33,6 aulas por ano, o Doutor Torquato de Sousa Soares abordava 10 a 15 temas distintos. Mas nem sempre eram os mesmos, pelo que a análise dos seus livros de sumários permite identificar, grosso modo, uns 20 a 25 temas que foram objecto do seu ensino entre 1942 e 1972. De entre todos esses temas, distingue-se perfeitamente um 'núcleo duro' de quatro, por estarem presentes em todos os anos lectivos e por lhes ser dedicado um número de aulas particularmente elevado (na maioria dos anos lectivos, 20 aulas ou mais para o conjunto desses temas). Os quatro temas de que falamos são os seguintes:

- a história da formação dos reinos bárbaros;

- a história do Islão ${ }^{12}$;

- a história de França, desde a constituição do reino Franco até ao advento da dinastia capetíngia (ou seja, a França merovíngia e carolíngia);

- e por fim, e inevitavelmente, o "feudalismo";

Em segunda linha encontramos, em muitos daqueles 20 anos lectivos mas regra geral sendo objecto de um tratamento muito menos generoso, temas como "o Império Romano" (que excepcionalmente, no ano lectivo de 1946-47, foi objecto de estudo em 17 aulas!), a "noção de Idade Média", a "Reconquista" e "a formação das comunas". Muito mais raramente, temos também registo de aulas (ou de partes de aulas) considerando temáticas como "Bizâncio", a "França capetíngia", a "história das cidades italianas", a "história do papado

12 Por "Islão" entenda-se, em 1942-43 (abordagem do tema em seis aulas distintas): a Arábia pré-islâmica; o aparecimento dos Árabes na História da Civilização; a vida de Maomé; Árabes e Berberes; a conquista da Península Hispânica pelos Árabes; o estabelecimento dos Muçulmanos na Península Ibérica; e a penetração dos Muçulmanos na Gália. E em 1971-72 (o outro extremo do diagrama, com a temática a ser tratado ao longo de três aulas): o advento do Islão; a Arábia pré-islâmica e Maomé; a doutrina religiosa do Corão e o triunfo desta; a unificação da Arábia; a conquista da Síria e da Pérsia; o Califado hereditário e o advento dos Omíadas; a conquista do Egipto e a progressão no Mediterrâneo; as consequências da expansão dos Maometanos a nível político, social e económico; e o avanço dos Muçulmanos: a conquista da Hispânia e a entrada na Gália. 
e/ou da reforma gregoriana" e a "história de Inglaterra"13. Quanto às "Cruzadas", apenas parece terem sido consideradas em quatro anos lectivos (e em cada um destes casos em três aulas diferentes), enquanto a "Guerra dos Cem Anos" apenas surge com alguma evidência (abordagem em três aulas distintas) no ano lectivo de 1971-72 (curiosamente, o último ano lectivo completo do Doutor Torquato de Sousa Soares).

Em síntese, o magistério de Torquato de Sousa Soares incidia esmagadoramente sobre uma cronologia que podemos situar entre a crise do Império Romano do Ocidente (sécs. III-V d.C.) e os finais do séc. X (com a generalização do feudalismo e o advento, em 987, da dinastia capetíngia). Além disso, é bastante nítido que (exceptuando o caso específico das primeiras aulas sobre o Islão) o seu ensino privilegiava uma geografia ibérica e gaulesa, com escassíssimas incursões pela Itália e a Inglaterra. Finalmente, podemos dizer que a atenção do docente se distribuía de forma aparentemente harmoniosa entre a história política, a história económica e social e a história religiosa.

Como seria de esperar, a consulta dos livros de sumário do Doutor Avelino de Jesus da Costa, nos anos em que este docente de tão grata memória assegurou as aulas práticas da cadeira do Doutor Torquato de Sousa Soares (nomeadamente a série ininterrupta de 1951-52 a 1956-57) confirma a impressão anterior. Os quatro temas principais são os tratados em aula teórica (reinos bárbaros, história da França merovíngia e carolíngia, Islão e feudalismo), ainda que seja de notar um alargamento interessante na abordagem da 'questão islâmica' 14 . Essa diversificação reaparece, aliás, nos livros de sumário de 1968-69 e 1969-70, anos lectivos em que, como já dissemos, coube ao Doutor Avelino de Jesus da Costa assegurar, ele próprio, as aulas teóricas e práticas de "História da Idade Média". Se a base permanece a mesma, é interessante notar uma maior atenção à

${ }^{13}$ Neste caso, não mais do que: a constituição da monarquia inglesa; o advento de Eduardo-o-Confessor; a conquista normanda de 1066 e suas consequências políticas; o parlamentarismo inglês; e as relações económicas e políticas da Inglaterra com o continente.

${ }^{14}$ Por exemplo, em 1956-57 (ano em que leccionou 11 aulas práticas da cadeira em apreço), nas três aulas em que considerou o tema do Islão, o Doutor Avelino tratou os seguintes aspectos: os pactos impostos pelos Muçulmanos aos Cristãos; as diversas atitudes dos Muçulmanos para com os Judeus e os Cristãos e para com os pagãos e idólatras; as mudanças de capital e a orientação política e cultural dos Muçulmanos: Meca, Damasco, Bagdad; os pactos entre Muçulmanos e os governadores cristãos peninsulares (análise de textos); as condições da ocupação árabe da Península Ibérica; e, finalmente, a revolta dos berberes e a sua acção na Reconquista. 
história da Inglaterra ${ }^{15}$, à história da França capetíngia ${ }^{16} \mathrm{e}$ à diáspora normanda. Da mesma forma, logo em 1973-74, o primeiro ano em que assegurou sozinha a leccionação da "História da Idade Média", a Doutora Maria Helena da Cruz Coelho (que já no ano anterior, em que até Março se ocupou apenas das aulas práticas do Doutor Sousa Soares ${ }^{17}$, dedicara uma atenção muito especial a um tema até aí pouco versado: as Cruzadas), mantendo intactas as principais opções do seu antecessor deixou uma marca pessoal inequívoca ao alargar a geografia da disciplina no sentido do Mediterrâneo Oriental e da Ásia Menor, concentrando o olhar sobre o Império Bizantino em pelo menos cinco das suas aulas ${ }^{18}$.

${ }^{15}$ Em 1969-70, o Padre Avelino leccionou 47 aulas de "História da Idade Média", tendo-se ocupado em pelo menos três dessas aulas da história de Inglaterra, abordando temas como: a invasão da Inglaterra pelos Anglo-Saxões; a divisão da Inglaterra em pequenos reinos; a invasão da Grã-Bretanha pelos Dinamarqueses; a sucessão de Eduardo-o-Confessor; Haroldo e o feudalismo inglês; Guilherme-o-Conquistador e a sua acção política e religiosa na Normandia; a conquista de Inglaterra (Hastings, 1066); a acção política, religiosa e administrativa: o Domesday Book; a sucessão de Guilherme; Henrique II e a sua personalidade, a centralização do poder e a luta contra os privilégios da Igreja; desterro e morte de Thomas Beckett, arcebispo da Cantuária; João Sem-Terra e a sua política relativamente à Igreja; a Magna Carta e a sucessão de João Sem-Terra.

${ }^{16}$ Em 1969-70, o Doutor Avelino de Jesus da Costa consagrou pelo menos duas aulas ao estudo da França capetíngia, nas quais desenvolveu os seguintes temas (até aí aparentemente pouco tratados): Hugo Capeto e a inauguração da nova dinastia; Luís VI e a luta contra o feudalismo territorial e de corte, contra a Inglaterra e contra a Alemanha; Luís VII e o seu carácter; a guerra contra a Inglaterra; o reinado de Filipe Augusto: personalidade, guerra com a Inglaterra e alianças com os filhos de Henrique II; Filipe Augusto e Ricardo-Coração-de-Leão na $3{ }^{\text {a }}$ Cruzada; Filipe Augusto contra João Sem-Terra (a batalha de Bouvines, 1214); e o reinado de São Luís: personalidade do monarca, instituições por ele criadas, a sua obra de assistência e a sua participação na $7 .{ }^{\mathrm{a}}$ e $8 .{ }^{\mathrm{a}}$ Cruzadas.

${ }^{17}$ A consulta dos sumários das aulas práticas de "História da Idade Média" leccionadas pela Doutora Maria Helena Coelho em 1971-72 permite observações muito interessantes: para além da consolidação e aprofundamento das matérias abordadas nas aulas téoricas do Doutor Torquato de Sousa Soares, procedia-se à leitura e comentário de textos documentais muito relevantes e de variados autores e temáticas (Gregório de Tours, Justiniano, Isidoro de Sevilha, Gregório Magno, Capitulares Carolíngias, Imperadores Otonianos, Gregório VII, Cruzadas, renascimento urbano, movimento comunal, etc.). Além disso, a docente já recorria à projecção de imagens (através de um episcópio) sobre assuntos tão variados quanto: as civilizações merovíngia, carolíngia, normanda e escandinava; ou a cavalaria e a vida senhorial típicas da época feudal 'clássica'.

${ }_{18}$ A título de curiosidade, e porque a História também se faz destes pequenos apontamentos, registe-se aqui o sumário da aula de "História da Idade Média" leccionada pela Doutora Maria Helena Coelho em 25 de Abril de 1974: "A segunda vaga de invasões na Europa: 1 - os Escandinavos: direcção e formas de expansão dos Noruegueses, Suecos e Dinamarqueses. Os ataques dos Normandos aos diferentes reinos do Império Carolíngio, até à criação da Normandia, em 911. O avanço dos Dinamarqueses para a Inglaterra; defesa do Anglo-Saxão, Alfredo-o-Grande; o reino de Carulo-o-Grande". Para dia de revolução, parece um sumário adequado... A aula seguinte teria lugar apenas a 7 de Maio de 1974. 
Para finalizar esta referência aos conteúdos programáticos no período anterior ao 25 de Abril de 1974, convém ainda recordar que existiu na FLUC, desde 1958-59 (i.é, na sequência da reforma de 1957), uma disciplina de "História da Cultura Medieval" obrigatória para os alunos de História e Filosofia, mas também para os de Filologia Germânica. Recordamos o facto porque este curso foi muito importante como complemento da formação dos estudantes da Faculdade de Letras de Coimbra em história medieval. Entre 1958-59 e 1973-74, a "História da Cultura Medieval" foi leccionada pelo Doutor José Maria da Cruz Pontes (na maioria dos anos lectivos), pelo Doutor Miguel Baptista Pereira (em 1961-62, em 1965-66 e em 1966-67), pelo Doutor Joaquim Ferreira Gomes (em 1963-64) ou em conjunto pelos Doutores Baptista Pereira e Ferreira Gomes (em 1962-63). Uma análise dos programas do principal docente da disciplina permite-nos identificar os principais temas do ensino do Doutor Cruz Pontes. Tomemos como exemplo o ano lectivo de 1970-71 (em que foram leccionadas 43 aulas teóricas e cinco aulas práticas): os conceitos de "cultura" e de "civilização"; a noção de "Idade Média" e sua evolução ao longo dos séculos; a Patrologia e a Patrística; as fontes escritas da Idade Média (noções de paleografia, códices medievais, etc.); os três elementos culturais fundadores da Idade Média (cultura greco-romana, Cristianismo e cultura bárbara); a afirmação e evolução do Cristianismo e o debate entre cristãos e pagãos (Celso, Félix, Tertuliano, entre outros); as heresias da Antiguidade Tardia (designadamente o Arianismo); os mestres alexandrinos; o imperador Constantino e o Cristianismo; o humanismo exegético de S. Jerónimo; a figura e o pensamento de S. Agostinho; a queda do Império Romano e a transição cultural (Boécio e Cassiodoro); o aparecimento do monaquismo no Ocidente e sua evolução na Alta Idade Média (S. Bento, reforma de Cluny); as heresias da Baixa Idade Média (Valdenses e Albigenses); as novas Ordens Religiosas (Franciscanos e Dominicanos); as escolas catedrais e o aparecimento das Universidades. Tais eram os temas principais, a que se associaram, em alguns dos outros anos, os seguintes: a cultura dos povos bárbaros; o aparecimento das historiografias nacionais; S. Isidoro de Sevilha, Gregório de Tours e a "Historia Francorum"; a cultura anglo-saxónica e as figuras de Teodoro, Adriano, Bento Biscop e Beda; o Renascimento Carolíngio; a acção de Gregório Magno; a importância da cultura árabe na Idade Média (autores, traduções, áreas privilegiadas, influência); a ciência e a filosofia judaicas; a evolução das Universidades ao longo do séc. XIII (Paris, Bolonha, Montpellier) e o apogeu da Escolástica. A bibliografia era sobretudo fornecida aos alunos durante as aulas, mas os livros de sumários conservam ainda assim os registos de alguns autores decerto mais recomendados: Bubler ("Vida y 
Cultura en la Edad Media"), G. Schnürer ("L'Église et la civilisation au Moyen Age"), Ferdinand Lot ("La fin du monde antique et le début do Moyen Age"), Henri Marrou (Saint Augustin et la fin de la cultura antique") e S. D'Irsay ("Histoire des Universités"). Nas aulas práticas, procedia-se sobretudo à leitura e ao comentário de fontes (exs: Tertuliano, Lactâncio, Atenágoras ou S. Agostinho).

Com a revolução de 1974 chegaria, como vimos, um novo plano curricular, mas nem por isso se pode dizer que o ensino da história medieval europeia na Universidade de Coimbra se tenha alterado profundamente. Na verdade, uma consulta dos livros de sumário da cadeira de "História das Sociedades Feudais", leccionada (entre 1975 e 1978) pelas Senhoras Doutoras Maria José Azevedo Santos e Maria Rosa Marreiros, permite facilmente constatar que os temas de longe dominantes nos respectivos programas eram sobretudo o Império Romano do Ocidente (na sua fase terminal), a constituição e configuração dos reinos bárbaros, a história da França merovíngia e carolíngia e, obviamente, o feudalismo (contrato feudo-vassálico, organização interna do senhorio, etc.). A reduzida carga horária desta disciplina (apenas uma aula de duas horas por semana, i.é., pouco mais do que 20 aulas por ano) e a circunstância de o plano de estudos em vigor prever, no ano lectivo seguinte (o $3 .^{\circ}$ ano do curso), uma disciplina de "História do Pré-Capitalismo e do Capitalismo Comercial" [leccionada também por medievalistas e com uma cronologia implícita que contemplava os séculos finais da Idade Média, a par da(s) primeira(s) década(s) da Época Moderna], fizeram da "História das Sociedades Feudais" uma disciplina (deveras interessante) centrada essencialmente na Antiguidade Tardia e na Alta Idade Média, geograficamente muito orientada para a Gália e privilegiando sobretudo a história política e a história sócio-económica. Pelo seu lado, a citada "História do Pré-Capitalismo e do Capitalismo Comercial", a cargo da Senhora Doutora Maria Teresa Nobre Veloso, cumpria também perfeitamente a missão que lhe fora confiada e o entendimento historiográfico que subjazia à própria designação da cadeira. Ou seja, afirmou-se como um curso marcadamente de história económica e social, muito centrado na problemática da reactivação da actividade comercial, da reanimação da vida urbana e da monetarização da economia dominial a partir dos sécs. XI-XII (com particular enfoque geográfico nas cidades italianas e hanseáticas, em certas regiões da França, como a Champagne, e na Flandres) e, numa fase mais avançada, na Crise do Século XIV (nos seus aspectos estritamente económicos mas também nas suas repercussões sociais); não faltando também aqui, como já dissemos, um olhar problematizador sobre a Crise Nacional de 1383-85 - um 
tema, de resto, muito na moda nos já longínquos anos lectivos de 1974-75 a $1978-79^{19}$.

Bastante mais profundas se revelariam as consequências da renovação curricular encetada pela reforma (nacional, recordo) implementada em 1978 e cujos efeitos se fariam sentir a partir do ano de 1979-80, no que ao ensino da história medieval europeia (leccionada no $2 .^{\circ}$ ano do curso de História e Variantes) diz respeito. É claro que a possibilidade de repartir o ensino da história medieval por três disciplinas anuais obrigatórias (cada qual com duas aulas semanais de duas horas cada) permitiu uma exploração até aí impensável de muitos temas, alguns deles inteiramente novos. Pela nossa parte, tendo assegurado durante vários anos (alguns deles em companhia do Doutor António Resende de Oliveira) a leccionação da disciplina de "História Cultural e das Mentalidades (sécs. III-XIV)", centrámos a nossa atenção na análise das instituições, dos instrumentos e dos ideais de cultura do Ocidente europeu (França, Itália e Península Ibérica em particular), entre a Antiguidade Tardia e os finais da Idade Média, procurando ao mesmo tempo fazer uma história da evolução das atitudes mentais no domínio religioso ao longo daquele período, com natural enfoque no Cristianismo. Procurava-se que estes dois discursos (o cultural e o religioso-mental) fossem devidamente enquadrados do ponto de vista político, institucional e sócio-económico, ainda que isso pesasse relativamente pouco no conjunto do programa que, sob o conselho do Doutor Resende, tínhamos elaborado. Paralelamente, no âmbito da disciplina de "História Institucional e Política", o nosso colega José Antunes soube construir, com o apoio directo do senhor Doutor José Mattoso (que como vimos leccionou mesmo esta disciplina em Coimbra no ano de 1979-80, o ano da chegada da nova reforma ao 2 . $^{\circ}$ ano do curso), o programa que a nova lógica curricular lhe exigia: a consulta dos livros de sumários de "História Institucional e Política (sécs. III-XIV)" para os anos lectivos de 1979-80 a 1983-84 permitiu-nos recordar as linhas mestras de uma disciplina mais centrada numa cronologia que podemos facilmente situar entre a Antiguidade Tardia e os inícios da Baixa Idade Média (a não ser no que à história do pensamento político diz respeito, pois aí ia-se mesmo até ao séc. XIV) e com uma geografia que, de acordo com a boa tradição coimbrã, privilegiava essencialmente a Península Ibérica e a França, sem no entanto deixar de fora (como no tempo do Doutor Torquato de Sousa Soares) a expansão do Islão. A título meramente exemplificativo, repare-se na

${ }^{19}$ Não tendo sido possível localizar na FLUC os livros de sumário desta disciplina, servimo-nos aqui dos nossos próprios materiais de estudo desta cadeira, que tivemos o prazer de frequentar em 1978-79. 
distribuição dos temas pelas aulas do Doutor José Antunes em 1983-84: Império Romano (6 aulas); Reinos Bárbaros (7 aulas); França merovíngia e carolíngia (8 aulas); Feudalismo (4 aulas); História de Espanha e da Reconquista (7 aulas); Islão (4 aulas); Pensamento político (6 aulas); Reforma gregoriana e história da Igreja (3 aulas); Comunas (2 aulas); Outros temas ( 8 aulas) ${ }^{20}$.

Finalmente, do lado da "História Económica e Social (sécs. III-XIV)" (disciplina leccionada, na maior parte dos anos em que a reforma de 1978 esteve em vigor em Coimbra, pelo Doutor João Cunha Matos, mas a que esteve também ligada a Senhora Doutora Maria Teresa Veloso) encontramos, como seria de esperar, programas sobretudo centrados no acompanhamento da evolução da actividade económica ao longo daquele vasto período, com especial incidência na agricultura e no comércio (neste caso, sobretudo para os sécs. XI a XIII), sendo entretanto de destacar a atenção que era dada, não só à Crise do Século XIV, mas também, e antes disso, às "peregrinações em armas" em que se tornaram as Cruzadas, expressão de uma nova mobilidade social, fonte de mercados e pequenos empreendimentos e veículo de expansão da economia ocidental para o Oriente. Também a história social (numa perspectiva ampla, de estratificação em grandes grupos ou ordens, ou mais circunscrita, micro-cósmica, familiar) esteve bem presente nestes programas, em íntima conexão com as transformações económicas previamente descritas e onde a análise dos recursos fornecidos pela vida rural e pela primitiva actividade artesanal/oficinal e o próprio desenvolvimento dos mercados encontrou também, com dignidade, o seu espaço próprio.

${ }^{20} \mathrm{O}$ total perfaz 55 aulas, um pouco mais do que aquelas que um ano lectivo de cerca de 25 semanas (ou até um pouco menos) comportava, pela simples razão de que em algumas aulas foi abordado mais do que um tema. Por curiosidade, aqui fica a memória dos principais assuntos abordados em alguns daqueles temas: História de Espanha = a hegemonia de Castela na Península; a formação da monarquia asturo-leonesa; Navarra e Aragão; Castela sob o domínio de Fernando Magno; os reinados de Afonso VI e Afonso VII e a centralização operada por Afonso X; a união das coroas de Castela e Leão; a unificação definitiva com os Reis Católicos. Islão = as instituições árabes na Península Ibérica; a comunidade islâmica antes da conquista da Península Ibérica; Maomé, fundador do Islamismo; características da comunidade islâmica; o Direito e as suas fontes; a djihad; a unificação da Arábia por Maomé; a conquista da Península Ibérica pelos Árabes; as instituições árabes na Península Ibérica. Pensamento político medieval = Jonas de Orleães; Hincmar de Reims; o desvio do pensamento agostiniano; o agostinismo político; as teses de Gregório VII; opiniões acerca da supremacia eclesiástica no séc. XIII; a oposição à teocracia papal e a Questão das Investiduras; os arnaldistas; os valdenses; Joaquim de Fiore e os franciscanos espirituais; S. Tomás de Aquino; os papas Inocêncio III, Inocêncio IV e Bonifácio VIII e a teoria do poder; o lugar dos sécs. XIV e XV no pensamento político medieval; Marsílio de Pádua, John Wycliff e Jan Hus; os papas de Avinhão; os principais teóricos oposicionistas da política papal; a Igreja e as correntes de laicização nos finais da Idade Média. 
Como já sabemos, a 'reforma nacional' esteve em vigor apenas até ao ano de 1986-87, sendo substituída por um novo plano de estudos, de concepção local. Assistiu-se então à fusão das três disciplinas referenciadas numa única "História da Idade Média". Com que repercussões programáticas? Tendo acompanhado de perto este processo, podemos testemunhar que, como sempre acontece com a chegada de uma nova solução curricular, tudo dependeu da decisão dos docentes. Em alguns casos, o programa antigo foi conservado, mutatis mutandi, enquanto noutros se procurou repensar a formação dos novos alunos, tentando equilibrar, em sínteses nem sempre fáceis de conseguir, as várias vertentes da História. No fundo, o dilema colocou-se ao nível da escolha entre um programa sincrético, mas mais superficial, e outro mais dirigido para determinadas áreas da grande História, onde os temas dessa área podiam merecer um detalhe razoável, mas onde o resto corria o risco de ficar, de certa maneira, entre parênteses. De acordo com o nosso entendimento pessoal do que poderia ser mais importante a este nível (mais elementar) de formação, privilegiámos sempre a primeira alternativa, mas respeitamos em absoluto a existência de opiniões distintas. De resto, como já tivemos a oportunidade de referir, a diversidade das soluções adoptadas pelos docentes encarregados do ensino da "História da Idade Média" entre 1987-88 e 2003-2004 também foi um factor de enriquecimento do nosso curso e permitiu aos alunos a escolha da sua turma em função, não só de factores tradicionais (horário, por exemplo), mas também dos próprios programas, o que é sempre salutar.

A partir de 2003-2004 entrou em vigor, como já adiantámos, uma nova reforma curricular, que tornou as cadeiras semestrais. A partir de então, o ensino da História da Idade Média europeia ficou entregue, em Coimbra, à Doutora Maria Teresa Veloso e a mim próprio. Porém, os programas de "História da Idade Média I" e de "História da Idade Média II" não se distinguiam substancialmente dos da sua antecessora directa (a "História da Idade Média"). Não obstante, a redução da carga horária e a própria adaptação ao regime semestral obrigaram a ajustamentos, do mesmo modo que foi necessário escolher criteriosamente o momento do corte cronológico na separação dos semestres. Neste particular, ambos os docentes optaram pelo século XI, julgo que com bons argumentos, quer do ponto de vista da história económica quer no que toca à evolução dos poderes régio e eclesiástico e mesmo no que tem que ver com a história cultural e das mentalidades. Pela minha parte, devo no entanto assinalar que consolidei uma revisão programática já parcialmente iniciada em 2002-2003 e em grande medida resultante da minha aprendizagem no ano que trabalhei em França como Professor Convidado (Université Paul Valéry, Montpellier III, 2001-2002): uma atenção especial à evolução da situação política no conjunto 
da Itália, incluindo a Sicília (sobretudo entre os sécs. X e XV); e um ênfase muito maior no estudo das Cruzadas.

No fundo, foi esta herança que tanto eu como a Senhora Doutora Maria Teresa Nobre Veloso acolhemos, e a que demos continuidade, a partir de 2007-2008, o ano da entrada em vigor da chamada "reforma de Bolonha". É certo que as disciplinas têm agora uma outra nomenclatura ("História da Idade Média" e "Temas de História Medieval"), mas no essencial elas são filhas da "História da Idade Média I" e da "História da Idade Média II". Uma consulta, ainda que superficial, dos livros de sumários (ou, a partir de 2008-2009, dos respectivos registos informáticos) comprova imediatamente isto. Se assim foi, isso deveu-se à circunstância de ambos os docentes terem concluído ser virtualmente impossível apresentar num só semestre, a alunos cada vez mais frágeis culturalmente e mais mal preparados (que surgem agora no $1 .^{\circ}$ e já não no $2 .^{\circ}$ ano dos seus cursos, pormenor não despiciendo), uma síntese da história da Idade Média na sua totalidade (i.é, cobrindo uma cronologia situada entre os sécs. V e XV). A impossibilidade de o fazer de uma forma séria (pois isso implicaria expor, em apenas 12 a 14 semanas, as grandes linhas de força da queda do Império Romano; da formação dos reinos bárbaros; da experiência do reino franco no período merovíngio; do Império Carolíngio; da construção, afirmação e desagregação da sociedade feudal; do crescimento económico e urbano dos sécs. XI-XIII; da reforma gregoriana e da teocracia papal; e da recuperação do poder régio nos sécs. XIV e XV - isto para me cingir aos pontos de referência principais) acabou por 'matar' aquele que terá sido, provavelmente, o espírito original da disciplina de "Temas de História Medieval" (vide supra). A realidade é que não parece possível levar, sem saltos bruscos e cientificamente incompreensíveis, a disciplina de "História da Idade Média" até uma cronologia posterior ao séc. XI, tal como já sucedia antes com a "História da Idade Média I". Portanto, o curso de "Temas" acaba por ser o prolongamento (cronológico) natural do anterior, da mesma forma que acontecia com a cadeira de "História da Idade Média II"...

Em conformidade, no ano lectivo de 2010-2011 a Senhora Doutora Maria Teresa Veloso leccionou, em "História da Idade Média", os seguintes três grandes temas: i) as invasões bárbaras e muçulmanas e a astenia mercantil do Ocidente; ii) os Carolíngios e a anarquia feudal; iii) a Igreja Católica e a nova ordem europeia. Quanto ao curso de "Temas de História Medieval", a mesma docente estruturou-o também de forma tripartida e tal como segue: i) a restauração da vida urbana; ii) a internacionalização da actividade comercial; iii) a transição da Idade Média para o Humanismo. Ou seja, nem há temas de história europeia dos sécs. XII a XV no curso de "História da Idade Média", nem há matérias de história da Alta Idade Média no seu programa de "Temas 
de História Medieval". Convém, no entanto, sublinhar a atenção dedicada pela docente, no âmbito do curso de "Temas de História Medieval", à Hispânia cristã designadamente quando procede ao estudo da evolução urbana (realçando as particularidades da Ibéria cristã decorrentes das peregrinações e da Reconquista), ou dos particularismos religiosos ibéricos (com a entrada da Reforma gregoriana na Península e com as inevitáveis transformações religiosas e culturais daí resultantes), ou ainda dos primeiros momentos da ideia de Cruzada (desde a conquista de Barbastro até à batalha de Las Navas de Tolosa).

Quanto a mim, a opção geral foi, como já disse, muito semelhante (sendo que esta coincidência de escolhas beneficia os alunos que transitam de um docente para outro entre os dois semestres). Nos anos em que pude leccionar (por estar liberto de funções de gestão universitária que me ocuparam vários anos entre 2003 e 2010, sobrecarregando assim a Doutora Maria Teresa Veloso com a totalidade dos alunos) organizei do modo que segue as minhas opções (cf. programas de 2008-2009, os mais recentes que posso citar). Em "História da Idade Média": i) agonia e queda do Império Romano do Ocidente (sécs. III-V); ii) a formação dos reinos germânicos e a evolução do reino Franco sob as dinastias merovíngia e carolíngia (sécs. VI-IX); iii) a sociedade feudal (sécs. IX-XI).E em “Temas de História Medieval”: i) as mutações dos finais do séc. XI e dos sécs. XII e XIII (vida económica e social; Igreja e vida religiosa; realeza e vida política em França, na Itália e, muito brevemente, na Península Ibérica; as Cruzadas na Síria-Palestina); ii) a Europa nos finais da Idade Média (sécs. XIV-XV: a crise do séc. XIV; a Guerra dos Cem Anos; e a reconstrução política europeia do séc. XV: França, Itália e Península Ibérica).

Por fim, vale a pena referir que, na Faculdade de Letras da Universidade de Coimbra, existem actualmente algumas disciplinas de opção que completam e, julgo, enriquecem os estudos de História Medieval. São os casos, pelo menos, da "História da Universidade I" (leccionada pela Doutora Maria Teresa Veloso e onde é estudado o declínio da cultura profana e o advento das letras cristãs, bem como a formação do curriculum medieval leccionado nas escolas, incluindo as Universidades), de "História da Cultura Medieval" (leccionada pelo Doutor António Resende de Oliveira e com incidência quer na cultura clerical quer na cultura profana dos meios régios e senhoriais) e ainda de "História Militar I" (leccionada por mim e centrada no estudo da arte militar antiga e, sobretudo, medieval, incluindo castelologia, armamento, história social, modelos tácticos e história das mentalidades).

Donde se pode concluir que, ao longo dos últimos 25 anos (entre 1986 e 2011), a história medieval europeia tem sido ensinada na Universidade de 
Coimbra em modalidades e com opções programáticas distintas mas que, no essencial, respeitam as principais opções tomadas pelos Mestres anteriores, desde o magistério do saudoso Doutor Torquato de Sousa Soares entre 1942 e 1972. Coube essencialmente a três docentes o ensino deste longo e fascinante período daquilo a que hoje chamamos "Europa": às Senhoras Doutoras Maria Teresa Veloso e Rosa Marreiros, para além de mim próprio.

No caso da Senhora Doutora Teresa Veloso, temos tido um ensino preocupado em cobrir um espaço cronológico bastante amplo (da decomposição da "ordem" romana e das invasões bárbaras às grandes convulsões do século XIV e à transição para a Europa do Humanismo), mas especialmente atento aos aspectos sócio-económicos (evolução do comércio e da circulação monetária, contrato feudo-vassálico, vivência urbana, organização do trabalho) e culturais-religiosos (tanto no que diz respeito ao pensamento eclesiástico, como no que toca à influência social da Igreja e ao aparecimento de novas ordens religiosas) e dentro de um espaço claramente centrado na França, na Itália (em particular no que aos aspectos comerciais e urbanos diz respeito) e na Península Ibérica, e, subsidiariamente, na Inglaterra e no Norte da Europa (também aqui em consequência da constituição das grandes alianças comerciais entre cidades que consolidam a renovação comercial dos séculos XII e XIII) ${ }^{21}$. Pelo seu lado, a Senhora Doutora Maria Rosa Marreiros (que entretanto se aposentou) assumiu uma preferência clara pelos aspectos económicos e sociais, sem no entanto descurar completamente outras vertentes, designadamente a política (com uma atenção pouco vulgar à evolução do exercício do poder sob a dinastia capetíngia) e mesmo a cultural (por exemplo no que toca ao chamado "Renascimento carolíngio", ou à laicização da cultura característica dos finais da Idade Média), trabalhando numa cronologia que podemos situar entre os séculos V e XIV e numa geografia que coincidia, no essencial, com a França ${ }^{22}$.

${ }^{21}$ Convém, no entanto, explicitar que o ensino da história política (invasões bárbaras, invasões árabes) e de alguma história cultural (ex: "Renascimento carolíngio") e das mentalidades (p.ex. para o séc. XIV), assim como uma reflexão sobre o movimento das Cruzadas (em particular

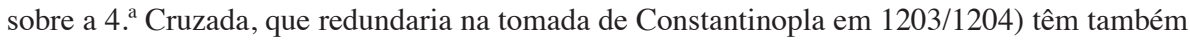
estado presentes na maioria dos programas apresentados pela Doutora Teresa Veloso.

22 Já no programa de "História da Idade Média" que, em 1997, apresentou a concurso para Professora Associada da Faculdade de Letras da Universidade de Coimbra, a Doutora Rosa Marreiros justificou a escolha da Gália por "vários factores, nomeadamente o facto de o mundo franco se revelar um bom campo de observação de dois fenómenos que estão na origem da civilização do Ocidente medieval. Referimo-nos, concretamente, à fusão do elemento romano com o elemento germânico e ao aparecimento de um novo sistema de relações sociais de produção - o feudal. A esta circunstância, e também ao facto de o mundo franco ser a realidade mais próxima da Península Ibérica, se juntaram algumas motivações de ordem prática, nomeadamente a 
Quanto a nós, temos procurado um equilíbrio entre as diversas valências da História, embora utilizando a história política como fio condutor da nossa narrativa; simultaneamente, temos tentado 'empurrar' até aos finais do séc. XV o terminus ante quem do nosso programa, claramente centrado no Mediterrâneo (França, Itália, subsidiariamente a Península Ibérica), mas incluindo aqui o Mediterrâneo Oriental (em torno da grande aventura das Cruzadas); se o calendário escolar o permitisse, gostaríamos muito de, um dia, incluir ainda uma história breve do Império Bizantino.

Comparando com o ensino da primeira fase da nossa amostra (1941-1986) julgamos que se nota sobretudo uma menor atenção a três temas: Islão, história de Inglaterra e Bizâncio. Mas, por outro lado, a história da Itália medieval (e, por arrastamento, a do Sacro Império Romano-Germânico) entrou claramente nos programas, ao mesmo tempo que o tema das Cruzadas ganhou uma maior relevância. O mesmo se diga da Guerra dos Cem Anos (e suas consequências), cuja valorização traduz também a intenção dos mestres mais recentes de conduzir os seus programas até um período mais tardio (meados-finais do séc. XV), facilitando uma articulação mais harmoniosa com o estudo da História da Época Moderna. Como temáticas prioritárias 'permanentes' nestas sete décadas é fácil eleger cinco: queda do Império Romano do Ocidente e formação dos reinos bárbaros; história do reino Franco nas dinastias merovíngia e carolíngia; sociedade feudal; crescimento económico dos sécs. XI-XIII (e suas implicações sociológicas e culturais); e história da Igreja e do Papado (em especial nos sécs. XI-XIV).

Em matéria de orientação bibliográfica, o ensino da história medieval europeia na Universidade de Coimbra mantém uma fidelidade interessante à tradição académica francesa (Marc Bloch, Henri Pirenne, Marcel Pacaut, F. L. Ganshof, Georges Duby, Jacques le Goff, Robert Fossier, Guy Fourquin, Jacques Heers, Jacques Paul - autores que têm muitas obras traduzidas em língua portuguesa), mas renovada por autores mais modernos e por títulos bastante sugestivos (p. ex., de Jean Flori, de Claude Gauvard ou de Dominique Barthélemy, entre outros) e, claro, ponderada com equilíbrio a questão do domínio de línguas estrangeiras pelos nossos actuais alunos, abrindo a novas correntes historiográficas, designadamente a espanhola e a anglo-saxónica (não tanto a italiana, até ver).

existência, nesta Faculdade, de algum material didáctico e de uma vasta e actualizada bibliografia referente a esta região, neste período" (p. 7). 


\section{Breve panorama comparativo}

Não cabe aqui proceder a uma comparação exaustiva do que tem sido o ensino da história medieval europeia na FLUC com o que se tem passado nas outras universidades portuguesas. Ainda assim, e para completar a nossa viagem, tivemos a oportunidade de dirigir a nossa atenção para dois tipos de materiais que nos parece interessante evocar aqui: por um lado, para um estudo que analisa o ensino da história da Idade Média na Faculdade de Letras do Porto nos anos imediatamente anteriores ao 25 de Abril; por outro, para os programas de história medieval (geral) que são actualmente leccionados nas Universidades do Minho, do Porto, de Lisboa ('Clássica' e Nova) e de Évora. Muito sucintamente, porque o espaço é limitado, vamos dar conta dos resultados dessa observação.

A produção, em 2004, de uma dissertação de Mestrado em "História Medieval", em que se analisa justamente o ensino e a investigação da História da Idade Média na Faculdade de Letras da Universidade do Porto entre os anos de 1962 e 1974, permitiu-nos conhecer um pouco melhor a história daquela instituição no que a esta temática diz respeito ${ }^{23}$. Nas páginas que dedica ao ensino da "História da Idade Média" (pp. 81-89), a Autora distingue três "fases de docência". Na primeira (que situa entre os anos de 1965-66 e 1968-69, sendo responsável pelas aulas teóricas da disciplina o Senhor Doutor Sérgio Silva Pinto), para além da discussão do conceito de Idade Média e respectivos limites cronológicos, estudavam-se "os três grandes centros da civilização medieval" (Bizâncio, Germânia e Islão), sendo a matéria mais generosamente tratada composta pelo estudo das Invasões Germânicas e dos diversos povos germânicos (procedendo-se mesmo à leitura e comentário crítico, "até ao mais ínfimo pormenor", da Germânia de Tácito); no ano de 1968-69, introduziu-se também a abordagem da "génese das estruturas políticas, económicas e sociais do "feudalismo"”. A segunda fase corresponde aos anos lectivos de 1969-70 a 1972-73, sendo único docente da cadeira o Senhor Doutor Luís Adão da Fonseca. Os conteúdos programáticos são "os mesmos (...), embora com mais profundidade" e "com maior rigor terminológico". Continua a dar-se um grande destaque ao estudo dos povos germânicos e à constituição

${ }^{23}$ A Autora do estudo é Regina Telo Padrão e o título exacto do trabalho é "A História Medieval na Faculdade de Letras da Universidade do Porto (1962-1974): ensino e investigação" (Porto, 2004, dactil.). Esta dissertação foi orientada pelo Senhor Doutor Armando Luís de Carvalho Homem, tendo sido defendida (e aprovada com "Muito Bom") em provas realizadas no dia 21 de Janeiro de 2005. Tivemos acesso a este estudo por cortesia da Senhora Doutora Maria Helena da Cruz Coelho. 
dos diversos reinos bárbaros no Ocidente europeu, com particular ênfase no reino Franco: "o estudo do Império Carolíngio é o mais aprofundado, tendo-lhe sido dedicadas seis aulas teóricas e duas práticas, enquanto que ao estudo dos outros reinos é somente dedicada uma aula teórica". Entretanto, vários outros temas completam o programa, designadamente "a economia agrícola no Ocidente europeu nos séculos VII-XI; a vida comercial no Ocidente nos séculos VIII-XI; o Feudalismo; a evolução económica no Ocidente nos sécs. XI-XIII". Nas aulas práticas, prosseguia-se a leitura e comentário do opus magnum de Tácito (embora menos intensivamente e a par de Jordanes), sendo os alunos estimulados para a apresentação de trabalhos de pesquisa sobre determinados pontos concretos, e muito variados, do programa. Finalmente, a terceira etapa restringe-se ao ano lectivo de 1973-74, tendo as aulas de "História da Idade Média" da Faculdade de Letras do Porto sido então asseguradas pelo Senhor Doutor Eugénio dos Santos. "As grandes linhas programáticas pouco diferem dos anteriores anos lectivos; contudo, este docente irá mais longe, ao referir-se (...) às novas técnicas agrícolas". Assim, a maior parte das aulas é dedicada ao estudo das invasões germânicas e à configuração dos diversos povos germânicos, seguindo-se as invasões muçulmanas na Península Ibérica, o Império Carolíngio, as diversas vagas de novos povos invasores (Normandos, Eslavos, Húngaros), a economia da Alta Idade Média, o feudalismo e, por fim, "o ressurgimento da Europa a partir do ano 1000: crescimento populacional, melhoria técnica, os novos aproveitamentos de terras, secagem de pântanos, a vida no campo, a atrelagem do cavalo por coleira, o jugo frontal, o emprego do cavalo em lugar do boi, e a rotação trienal".

Em síntese, poderá dizer-se que o ensino da "História da Idade Média" na Faculdade de Letras do Porto entre os anos de 1965 e 1974 cobria essencialmente o período compreendido entre a queda do Império Romano do Ocidente (em 476) e o renascimento económico e urbano dos sécs. XI-XII, dedicando uma atenção muitíssimo especial à constituição dos reinos bárbaros no Ocidente europeu (e, em particular, ao caso concreto do reino Franco, sobretudo no período carolíngio) e, subsidiariamente, à génese e implantação do feudalismo. Privilegiava-se sobretudo a história política e a história económico-social, dentro de uma geografia eminentemente 'gaulesa' (o que ajuda também a explicar a preferência, em termos de orientação bibliográfica, por autores como Ferdinand Lot, Marc Bloch, Marcel Pacaut, F. L. Ganshof ou Georges Duby). Parece, portanto, que as diferenças relativamente ao que se passava em Coimbra na mesma época não são particularmente grandes: muita atenção concedida à Alta Idade Média, particular ênfase dada à história económica e social, e análise criteriosa da história política - ao menos enquanto fio condutor das narrativas 
necessárias a introduzir em cena novos actores, em particular os Bárbaros e os Muçulmanos, e a explicitar a ascensão e a queda das grandes construções políticas, como o Império Carolíngio.

Resta fazer o prometido 'zoom' sobre os programas em vigor nas cinco universidades citadas, no ano lectivo de 2010-2011. Afinal, eles são o retrato do que se passa actualmente fora da FLUC em matéria de ensino da história medieval europeia e uma tal comparação parece-nos interessante. Viajaremos de norte para sul pelo que começamos pela Universidade do Minho (Instituto de Ciências Sociais). Aqui, o ensino geral da Idade Média é assegurado através de duas cadeiras semestrais obrigatórias da licenciatura em História: "História da Idade Média I" e "História da Idade Média II" (precisamente a solução que vigorou em Coimbra entre 2003-2004 e 2006-2007). Ambas as disciplinas estão a cargo do Doutor Arnaldo Sousa Melo. A "História da Idade Média I" cobre um arco cronológico que vai do séc. IV ao séc. X, ou seja, situa-se nos períodos da Antiguidade Tardia e da Alta Idade Média. Para a etapa situada entre os sécs. IV e VII são explorados sobretudo os seguintes temas ${ }^{24}$ : as transformações político-administrativas e militares; as condições materiais e sociais; a reorganização do espaço e as novas fronteiras políticas, em resultado das migrações/invasões a que o Ocidente europeu assistiu; e a evolução cultural e religiosa, com a afirmação do Cristianismo como religião dominante. Segue-se a análise da génese e evolução do monaquismo cristão: a construção da moral cristã (de S. Paulo a Santo Agostinho); a experiência dos Padres do deserto; e o aparecimento do monaquismo cristão e seu enquadramento posterior com a Regra de S. Bento de Núrsia. Por fim, cobrindo os sécs. VIII a X, aborda-se a Europa carolíngia: a nova realidade geo-política, a construção do Império, as alterações e permanências ao nível da economia e da sociedade e, a rematar, a evolução cultural e religiosa (procurando-se identificar aqui os elementos da "identidade europeia"). O díptico completa-se com o curso de "História da Idade Média II". Este acha-se organizado em dois capítulos principais. O primeiro é dedicado aos sécs. XI a XIII, sob o lema do "Crescimento". Aqui se abordam temas como a viragem do ano mil; o novo espaço da Cristandade ocidental; as condições para a expansão material; e as mutações da Igreja e da sociedade no seu conjunto. Segue-se a análise da sociedade medieval e do feudalismo (enquanto modelo ideológico e prática social). Vem depois a evolução política e institucional, com o estudo do Império e do Papado e a génese dos reinos

${ }^{24}$ Neste e nos casos que se seguem, não se trata aqui de proceder a uma enumeração exaustiva, que não seria viável, mas sim de uma selecção indicativa daqueles que nos parecem ser os temas principais dos programas em apreço. 
e dos Estados nacionais. Este primeiro capítulo remata com uma reflexão acerca da renovação urbana e da 'revolução comercial': evolução das cidades; relação entre economia e urbanismo; e expansão cultural e religiosa (com o chamado Renascimento do séc. XII e o aparecimento das Universidades). O segundo grande capítulo do curso de "História da Idade Média II" no Minho é dedicado aos sécs. XIV e XV: discute o conceito de crise(s), analisa as transformações e continuidades (demográficas, económico-sociais ou políticas) e termina com a construção do Estado e a transformação dos poderes políticos. Curiosamente, o docente intercala ao longo deste curso (ao ritmo de uma aula por semana) dois grandes temas, vocacionados para um trabalho de pendor mais prático: as Cruzadas (coincidindo com a primeira parte da matéria); e a evolução económica dos sécs. XIII a XV (trabalho, comércio, finanças, relação campo-cidade, mercados, espaços económicos, etc.), acompanhando a segunda parte da matéria 'principal'. Em ambas as cadeiras, a bibliografia de base assenta em obras em língua portuguesa (designadamente traduções de clássicos como J. Le Goff, G. Fourquin, M. Balard/J.-Ph. Genet/M. Rouche e G. Duby) ou em língua espanhola (J. A. García de Cortázar/J. A. Sesma Muñoz), embora a obra de referência de Averil Cameron (em língua inglesa) esteja também presente.

Na Universidade do Porto (Faculdade de Letras, Departamento de História e de Estudos Políticos e Internacionais), o ensino da história medieval europeia encontra-se distribuído por três disciplinas obrigatórias (tal como na reforma nacional de 1978-1986, mas agora todas elas semestrais): "História Económica e Social na Época Medieval", "História Política na Época Medieval" e "História da Cultura na Época Medieval". Trata-se de cadeiras do 1. ano da licenciatura em História, embora servindo também alunos de anos mais adiantados da licenciatura em Geografia. São disciplinas com uma carga horária semanal de quatro horas. Em 2010-2011, o curso de "História Económica e Social” esteve (como habitualmente) entregue à Doutora Paula Pinto Costa. O seu programa vai desde o fim do mundo antigo até ao séc. XV e encontra-se estruturado em três grandes capítulos: i) "Os fundamentos da civilização ocidental" (fim da Antiguidade; chegada dos povos germânicos, fusão romano-germânica e novo mapa político, com destaque para o reino dos Francos; formação da economia medieval, economia senhorial e domínio clássico; cidades na Alta Idade Média e origens da vida urbana; impacto do contacto com o Islão; e comércio de longo alcance); ii) "A Plena Idade Média" (expansão da vida material; revalorização técnica; evolução demográfica; meio local e meio urbano; enquadramento senhorial e renovação urbana; vitalidade do comércio, novas formas de crédito e de associação; relações sociais medievais e respectivo modelo ideológico: 
as três ordens; a cavalaria e as Cruzadas); iii) "Os séculos XIV e XV" (vida material e condições de eclosão da crise; mutações da sociedade medieval; e superação das dificuldades). O apoio bibliográfico de base é assegurado pelas obras de A. Palenzuela, S. Claramunt et alii e L. Adão da Fonseca (em espanhol), Guy Fourquin e Michel Balard et alii (em traduções portuguesas) e R. Fossier (em francês). Em 2010-2011, o curso de "História Política na Época Medieval" (geralmente a cargo do Doutor Armando Luís de Carvalho Homem, actual Director do Departamento) foi assegurado pelo Doutor José Augusto de Sotto Mayor Pizarro com um programa organizado em três pontos principais: i) "Os fundamentos da civilização europeia" (transição do mundo antigo para o mundo medieval; invasões bárbaras e formação dos primeiros reinos ocidentais; organização e decadência da Europa carolíngia); ii) "Os séculos da Cristandade" (a paz, a Cristandade e os poderes temporais; vida política entre o séc. XI e os inícios do séc. XIV - a reforma gregoriana e o advento das monarquias; Reconquista na Península Ibérica); iii) "Os séculos XIV e XV" (crise do séc. XIV; estruturas políticas; vida política entre meados do séc. XIV e o séc. XV - Atlântico e Mediterrâneo Ocidental; Guerra dos Cem Anos; Itália; Castela e Aragão). A bibliografia principal baseia-se nas mesmas obras de A. Palenzuela, M. Balard e S. Claramunt indicadas para o curso anterior, mas, em vez do clássico de Robert Fossier, aparece-nos agora, compreensivelmente, o de Marcel Pacaut (também em língua francesa). Por fim, o curso de "História da Cultura na Época Medieval" esteve a cargo (como de costume) do Doutor Luís Miguel Duarte e apresenta uma estrutura quadripartida: i) "A herança da Antiguidade Tardia. Cristianismo e paganismo: do confronto à síntese" (com destaque para a Patrística, grega e latina); ii) "A Alta Idade Média, sécs. V-X" (os três vectores da cultura europeia: herança clássica, Cristianismo e cultura germânica; o monaquismo, a educação e o Renascimento carolíngio; as línguas vernáculas; a reforma eclesiástica e Cluny); iii) "A Idade Média Central, sécs. XI-XIII” (ano mil; 'Renascimento do séc. XII'; Universidades); iv) "A Idade Média Tardia, sécs. XIV-XV" (crise do séc. XIV; nova religiosidade; declínio das Universidades e diversificação cultural; primeiro Humanismo). Na bibliografia principal aparecem só títulos em língua portuguesa, de autores como J. Le Goff (o mais representado), M. Baniard, G. Duby, F. Lebrun, B. Price e Ph. Wolff.

Desçamos de seguida até Lisboa, uma vez que Coimbra já foi largamente considerada. Começaremos pela escola mais antiga, a Faculdade de Letras da Universidade de Lisboa. Curiosamente, encontramos aqui um modelo intermédio que passa por duas cadeiras semestrais, uma de "História Medieval (Política e Cultura)" e outra de "História Medieval (Economia e Sociedade)". 
Em ambos os casos, existe uma dupla oferta programática. Na "História Medieval (Economia e Sociedade)", um dos programas (em regime de aulas teórico-práticas) é proposto pela Doutora Manuela Santos Silva e acha-se sistematizado em cinco capítulos: i) "O fim da Época Romana e o princípio da Idade Média" (confronto civilizacional; decadência urbana; o Mediterrâneo bárbaro, bizantino e islâmico); ii) "A ruralização da sociedade ocidental" (as cidades na Alta Idade Média; o predomínio do senhorialismo); iii) "A sociedade feudal" (hierarquização social e direitos sobre a terra; senhores e vassalos; sociedade cavaleiresca); iv) "Revolução agrícola, revolução urbana e expansão do Ocidente" (explosão demográfica, progresso agrícola e renascimento das cidades; expansão do Ocidente e ressurgimento do comércio inter-regional); v) "A Crise e a sua superação" (retracção demográfica e mudanças sociais; (des)equilíbrios entre campo e cidade). Da bibliografia deste curso, bastante extensa (c. 60 títulos) e na sua maior parte em línguas portuguesa e espanhola, retivemos sobretudo a forte presença (c. um terço) de obras clássicas (mas sempre actuais) sobre o feudalismo e a sociedade cavaleiresca, de autores da 'escola francesa' como G. Duby (5 títulos), J. Le Goff (4), H. Pirenne (3), J. Heers (3), R. Fossier (2), L. Musset (2) ou Guy Fourquin (1).

A outra oferta de programa na disciplina de "História Medieval (Economia e Sociedade)" leccionada na FLUL deve-se à Doutora Julieta Araújo e acha-se também organizada em cinco partes distintas: i) "O final do Império Romano" (economia e sociedade no Baixo Império; o avanço dos bárbaros e os reinos bárbaros: organização política, económica e social); ii) "O Oriente romano" (o Império Romano do Oriente na época das invasões; Justiniano; o aparecimento do Islão: a Arábia pré-islâmica, Maomé, a expansão muçulmana e os Árabes no Ocidente); iii) "O encadeamento da Europa bárbara" (as cidades; os Francos; os reinos merovíngios; o Norte europeu; a influência bizantina no Mediterrâneo ocidental); iv) "A evolução do Ocidente, dos reinos bárbaros ao feudalismo" (a busca da unidade; a dinastia carolíngia; Carlos Magno e o Império: administração, governo, estratificação social e significado de 'vassalagem'); v) "Os sucessores de Carlos Magno" (separação do Império, instabilidade política e condicionantes externas; o Império Bizantino: política, administração, economia e sociedade; os Árabes: os Abássidas e o triunfo dos Fatímidas). Em termos de orientação bibliográfica, este curso, que como se vê valoriza bastante a componente islâmica e bizantina, propõe aos estudantes um conjunto muito seleccionado de obras bem conhecidas e respeitadas de autores franceses, quase todas traduzidas para língua portuguesa, com destaque para G. Duby e H. Pirenne (os autores mais representados), F. Ganshof, J. Gimpel, L. Halphen, J. Huizinga, F. Lot e D. Sourdel. 
Examinemos agora os dois programas da outra aba do díptico organizado na FLUL para o ensino da história medieval europeia. Ou seja, consideremos os dois programas oferecidos para a disciplina de "História Medieval (Política e Cultura)". O do Doutor Armando Martins foi mesmo objecto do Relatório da Disciplina recentemente apresentado por este docente a Provas de Agregação (FLUL, 2009). Examinámo-lo com atenção e percebemos que apresenta uma organização quadripartida: i) Antiguidade Tardia (sécs. V-VIII); ii) Alta Idade Média (sécs. VIII-XI); iii) Idade Média Central (sécs. XII-XIII); iv) Outono da Idade Média (sécs. XIV-XV). Como, excepcionalmente, a observação se fez aqui a partir do Relatório preparado para a Agregação, dispomos de elementos muito mais detalhados acerca dos conteúdos desta cadeira. Assim, na primeira parte o docente propõe-se considerar: o fim do Império Romano; os primeiros reinos bárbaros; o Império Romano do Oriente e a presença da cultura oriental no Ocidente; a progressão muçulmana para oeste; a situação na Península Ibérica; a evolução do Cristianismo na Antiguidade Tardia, a Patrística e a cultura monástica. Na segunda parte (sécs. VIII-XI), a escolha recai sobre: o Renascimento carolíngio e Alcuíno de York; as invasões do séc. IX (Normandos, Vikings, Magiares e Sarracenos); o Império na Alemanha (Sacro Império Romano-Germânico); a fragmentação política (castelos, senhores, cavaleiros, feudalismo) e a feudalização da própria Igreja (Cluny, os movimentos de paz, as escolas urbanas e a figura de Gerberto d'Aurillac); o take off do séc. XI; o avanço da Reconquista, a cultura moçárabe e o al-Andaluz; e a reforma gregoriana e a teocracia papal. Na terceira parte (sécs. XII-XIII) propõe-se os seguintes temas: o crescimento monárquico (a França e a Inglaterra); a sofisticação do governo central e seus aparelhos burocrático e legislativo; o movimento das Cruzadas e as Ordens Militares; a situação na Península Ibérica e os avanços da Reconquista no séc. XII; o 'renascimento urbano' do séc. XII; as cidades, os ofícios e as comunas; a evolução cultural e o contributo dos Árabes e dos Judeus (os centros de tradução: Toledo); as novas escolas (o exemplo de Santa Cruz de Coimbra); as Universidades e o balanço da 'cultura escolástica; o combate aos movimentos heréticos; e a cultura profana e o lugar da mulher. Por fim, na quarta parte (sécs- XIV-XV), este programa considera os temas clássicos do "Outono da Idade Média": a Crise do séc. XIV (Peste Negra, revoltas sociais, Cisma da Igreja, heresias, Guerra dos Cem Anos), com o olhar a incidir também sobre a Península Ibérica e Portugal (D. Fernando); a centralização do poder político e o Estado monárquico moderno; os casos alemão e italiano (cidades autónomas); o apagamento do Império; a conquista turca de Constantinopla e o fim do Império Bizantino; a dissolução da Escolástica e a afirmação do nominalismo e do empirismo; 
o misticismo, o anti-intelectualismo, a devotio moderna e o anti-individualismo; a transformação das Universidades; os alvores do Humanismo renascentista; e a evolução da cultura profana das cidades (mercadores, banqueiros, artistas e mecenas das artes e da literatura em língua vulgar). O suporte bibliográfico é assegurado por um conjunto de obras bem conhecidas dos especialistas: J.-Ph. Genet, Michel Rouche, M. Balard, J. Le Goff, G. Duby, H. Pirenne, L. White, M. Pacaut, L. Génicot, P. Riché, A. Boreau, J. Krynen, A. Gurevitch, G. Fourquin, J. Paul, J. Verger, J. Strayer ou B. Guenée, entre muitos outros. É visível o peso das obras francesas (apenas uma parte das quais foi objecto de tradução), mas deve também realçar-se a presença de vários títulos de autores portugueses (p. ex., de Maria Helena da Cruz Coelho ou A. L. de Carvalho Homem). Deve também salientar-se que o curso (pensado para 28 a 30 aulas) foi concebido para ser apoiado por um conjunto de filmes ou documentários audiovisuais, rematando com o visionamento de "O Nome da Rosa".

O outro programa de "História Medieval (Política e Cultura)" da FLUL é apresentado pela Doutora Margarida Garcez e tem também uma organização interna quadripartida: i) "A transformação do mundo romano" (revisão conceptual da ideia de queda do Império Romano; invasões bárbaras; relações entre Romanos e Bárbaros; cristianização do Império Romano; relações entre Estado e Igreja); ii) "Um dos sucessores de Roma no Ocidente: os Francos e o Império Carolíngio" (Clóvis e a dinastia merovíngia; a realeza franca; a expansão do Islão; Carlos Magno, o 'Renascimento carolíngio' e a queda do Império); iii) "Do mundo feudal à reconstrução das monarquias" (os novos invasores; as 'duas idades feudais' de Marc Bloch; a poliarquia feudal; a paz e a guerra, 'justa' ou 'santa'; as Cruzadas e as Ordens Militares; os elementos da reconstrução monárquica: reforma gregoriana, realeza, direito feudal e direito romano); iv) "Elementos de política e de cultura nos finais da Idade Média" (a recuperação económica e as cidades; as Universidades; o poder popular; a Peste Negra, a Guerra dos Cem Anos, o Cisma do Ocidente e as revoltas urbanas e camponesas; os movimentos milenaristas - Lolardos e Hussitas; o conceito de Estado Moderno; Galicanismo e Regalismo; minorias sócio-religiosas; o triunfo dos Otomanos - tomada de Constantinopla - e as ameaças à Cristandade). Na bibliografia sumária, reencontramos o manual de Balard-Genet-Rouche (traduzido em português), bastantes obras de Duby, Bloch, Le Goff e Delumeau (as mais recomendadas, a maioria em tradução portuguesa), mas também livros de B. Guenée, J. Quillet ou B. Ward-Perkins, para além de três trabalhos de Martim de Albuquerque e de alguns clássicos da história política em diversas línguas (p. ex., M. García-Pelayo, J. Krynen ou J. Strayer). Há também outros autores portugueses representados nesta bibliografia 
(como A. Hespanha, Manuela Mendonça, Veríssimo Serrão ou M. Garcez Ventura). Notaremos ainda que a autora lecciona aos alunos de História da Arte um outro curso, intitulado "História e Cultura Medieval", que revela (como seria de esperar) um pendor mais acentuado da componente cultural e religiosa, sem no entanto prescindir dos necessários enquadramentos políticos.

Como última observação, notaremos o que nos parece ser uma particularidade do ensino da história medieval europeia na FLUL: o elevado número de disciplinas de opção oferecidas aos alunos. Alguns exemplos: História das Ideias Políticas na Idade Média; Cristianismo Medieval; História Urbana Medieval; História Rural Medieval; História Militar Medieval; Quotidianos Medievais; História do Al-Andaluz; e História do Género na Idade Média.

Deixemos agora a Alameda da Universidade e viajemos até à Avenida de Berna, onde se localiza a Faculdade de Ciências Sociais e Humanas da Universidade Nova de Lisboa. Aqui, o ensino da história medieval europeia encontra-se atribuído a duas disciplinas com uma organização cronológica bastante convencional (semelhante à do Minho e, como veremos, à de Évora): "História Medieval (Séculos V-XI)" e "História Medieval (Séculos XII-XV)". A primeira ("História Medieval (Séculos V-XI)") esteve confiada em 2010-2011 ao Doutor Miguel Gomes Martins e o respectivo programa acha-se organizado em sete módulos. Se o primeiro é de natureza teórico-metodológica (dedica-se à historiografia sobre a Alta Idade Média), o segundo está centrado na crise política e militar do Baixo-Império e na instalação dos Bárbaros no Ocidente. Seguem-se módulos sobre a formação e o declínio dos reinos bárbaros, sobre o Império Bizantino nos sécs. V a XI, sobre a Europa carolíngia e, finalmente, sobre a territorialização do poder (invasões do séc. IX, divisão do poder político, disseminação dos castelos, sociedade do séc. X, sonho imperial otoniano) e sobre a ascensão das monarquias feudais (a evolução da vassalidade para a feudalidade, os senhores feudais, e a revitalização das grandes unidades político-territoriais). Na orientação bibliográfica sucinta, predomínio claro das obras (quase todas traduzidas para português) de Duby e Le Goff (os livros de ambos os autores representam perto de $50 \%$ da bibliografia de base), mas registamos também a presença significativa de autores anglo-saxónicos, como Peter Linehan, John Powell ou R. L. Storey, para além da indispensável New Cambridge Medieval History.

Este curso é harmoniosamente completado pelo de Maria de Lurdes Rosa, que lecciona a "História Medieval (Séculos XII-XV)". Repete-se aqui a organização em módulos, mas estes são agora em número de quatro: um dedicado à historiografia sobre a Baixa Idade Média; o segundo intitulado "A vitalidade de uma área civilizacional (sécs. XII-XIV)", no qual se analisa o desenvolvimento 
económico do período (agricultura, comércio, cidades), o sistema político (relações entre monarquias e Papado), os elementos mais importantes da história religiosa da época (Cister, mendicantes, heresias) e a vida cultural, intelectual e artística ('Renascimento do séc. XII', ensino e universidades, arte). O terceiro módulo trata os "Tempos de crise e de reconstrução (sécs. XIV-XV)" e constitui o momento para explorar assuntos como a(s) crise(s) do século XIV, a história institucional e política dos finais da Idade Média (guerra, aristocracia, Estado, 'Estado moderno'), a evolução económica e social (agricultura, comércio, cidades), a história religiosa do período (evolução da Igreja, vivências religiosas) e a vida cultural, intelectual e artística (atrofia da cultura eclesiástica, desenvolvimento dos saberes laicos, 'Renascimento'). Por fim, o quarto módulo é sobre "O Oriente e o Ocidente" nos séculos XII a XV. Aqui se trata o tema das Cruzadas e do mundo islâmico, assim como o Império Bizantino. As sugestões bibliográficas são muito semelhantes às da disciplina anterior (os dois cursos estão, aliás, bastante bem articulados), com as devidas adaptações. Para comodidade dos alunos, a docente destaca a importância da obra conjunta de M. Balard, J.-Ph Genet e M. Rouche, uma das várias obras de Duby (“A Europa na Idade Média”), dois títulos de Le Goff ("As raízes medievais da Europa” e, em colaboração com J.-Cl. Schmitt, o famoso "Dictionnaire raisonné de l'Occident médiéval") e uma obra de que Peter Lineham é editor ("The Medieval World").

Terminamos com a Universidade de Évora. Repete-se aqui o modelo de subdivisão do ensino da história medieval europeia em duas disciplinas semestrais separadas não pelas temáticas mas pela cronologia. Em 2010-2011, a "História Medieval I" esteve cargo do Doutor Filipe Themudo Barata. O seu programa comporta uma divisão em dois grandes territórios. O primeiro é sobre a desagregação do mundo antigo e a passagem para a "medievalidade" (sécs. III a VIII) e nele se abordam temas como: o fim da "paz romana", a crise do mundo urbano e a ruralização; as sucessivas invasões e migrações; a formação de um novo quadro político e social europeu (incluindo os reinos germânicos, o papel da Igreja, a continuação do Estado Romano do Oriente e as transformações da paisagem e da actividade agrícola); e a organização progressiva de um novo sistema de valores (cristianização do Ocidente, releituras da cultura clássica, papel da Igreja na construção da ideia de uma cultura medieval e ocidental). O segundo território, intitulado "A caminho da reconstrução e do reordenamento do Mundo", ocupa-se dos séculos IX e X e aqui se abordam as seguintes matérias: os Carolíngios e o ressurgimento do Império; a irrupção do Islão no Mediterrâneo; o reordenamento político e a sua diversidade; a intervenção da Igreja e a construção de um novo sistema de referências (as "três ordens", 
a cavalaria, a sagração da família e do casamento, as instituições feudo-vassálicas e a 'revolução feudal'); os grupos sociais, os poderes territoriais e a economia senhorial; e o monopólio da cultura pela Igreja (ensino, mosteiros e novas formas literárias no Ocidente). A bibliografia básica deste curso é composta por uma dezena e meia de títulos, metade em língua portuguesa e os restantes em Espanhol, Francês e Inglês; os autores mais representados são Guy Fourquin e Henri Pirenne, mas aqui se encontram também obras de referência (muitas delas traduzidas para português) de Marc Bloch, de Georges Duby, de F. L. Ganshof, de Jacques Heers, de Louis Halphen ou de Lucien Musset. Os títulos em língua inglesa dizem respeito a obras de Oliver Rackam (sobre a paisagem, a flora e a fauna britânicas) e de Warrem Treagold (a célebre síntese sobre o Império Bizantino). Este curso de "História Medieval I" tem a sua continuidade natural na disciplina de "História Medieval II", leccionada em 2010-2011 pelos Doutores Filipe Themudo Barata e Fernando Branco Correia. Aqui, temos também dois grandes capítulos. O primeiro, com o título "A estabilização de uma Europa em expansão (séculos XI a XIII)", encontra-se dividido em quatro unidades temáticas: i) "As bases da produção e do crescimento" (incremento demográfico, inovações técnicas, alterações da paisagem); ii) "A expansão e o crescimento" (agricultura, comércio, cidades, moeda, crédito); iii) "Conquista, estabilização e poder político" (Cruzadas e Reconquista; Papado e Império - lutas e tréguas; as grandes unidades politicas de base territorial); iv) "Concorrência e complexidade dos sistemas culturais" (ortodoxia e heresia; reforma gregoriana; línguas vernáculas e culturas nacionais; Universidades, Escolástica e S. Tomás de Aquino). O segundo grande capítulo intitula-se "A consagração das mudanças (séculos XIV e XV)" e nele achamos também quatro unidades temáticas, que abordam as seguintes matérias: i) "Um século de crise e transformação" (depressão demográfica, crise do senhorio rural, conflitos no mundo urbano e Guerra dos Cem Anos); ii) "Reestruturação e recomposição económica e social" (reconversão agrícola, arranque do pré-capitalismo industrial, evolução do comércio); iii) "Uma nova configuração política" (os Cismas, o reforço do poder real, o fim do Império Romano do Oriente); iv) "A mudança do mundo" (descoberta de novos parâmetros de espaço e tempo; desenvolvimento de uma cultura laica de raiz urbana; percepção das ciências e evolução do pensamento abstracto; e um quotidiano mais cuidado: mesa, moda e espaços da casa). A bibliografia básica deste curso é composta por 30 títulos (uma terça parte em língua portuguesa, os restantes em Espanhol, Francês e Inglês), muitos dos quais idênticos ao do curso anterior. Georges Duby, Guy Fourquin, Henri Pirenne e Chris Wickham (duas sínteses sobre a história da Europa e 
do Mediterrâneo, uma entre 400 e 800 e outra entre 400 e o ano 1000) são os autores mais representados.

Depois desta viagem, e para terminar o nosso texto, uma vez que o caso de Coimbra surge perfeitamente 'em linha' com os restantes cumpre fazer um comentário final actualizado acerca do ensino da história medieval europeia nas Universidades do Minho, Porto, Coimbra, Clássica de Lisboa, Nova de Lisboa e Évora. Começamos por notar a existência de dois grandes modelos de organização curricular. O Minho, a Nova e Évora dispõem de duas cadeiras com uma organização cronológica sequencial, do tipo História Medieval I e História Medieval II (ou designação equivalente), separadas no século X (Minho e Évora) ou no século XI (Nova). Já o Porto e Lisboa (Clássica) apresentam uma distinção de natureza temática: Lisboa divide em dois (Economia e Sociedade de um lado, Política e Cultura do outro) e o Porto divide em três (Economia e Sociedade; Política; Cultura). Curiosamente, Coimbra tem, em teoria, um modelo diferente de todos os outros, com a "História da Idade Média" e os "Temas de História Medieval”, mas já vimos que - na prática - acaba por trabalhar dentro do mesmo paradigma das Universidades do Minho, da Nova e de Évora.

Segunda observação: em todas as universidades, o espectro cronológico abrangido pelas disciplinas que asseguram, em conjunto, o ensino da história medieval europeia é semelhante, estendendo-se da decadência e crise do Império Romano do Ocidente (sécs. III, IV ou V) até ao século XV (mais propriamente até meados de Quatrocentos, se não erramos). Apesar dessa convergência global, a periodização interna apresenta algumas nuances: hoje em dia, a divisão tradicional (Antiguidade Tardia, Alta Idade Média e Baixa Idade Média) convive já com uma outra, quadripartida: Antiguidade Tardia, Alta Idade Média, Idade Média "Central” (ou "Plena”) e Idade Média "Tardia” (ou "Outono da Idade Média”, ou, simplesmente, Séculos XIV e XV). Esta solução quadripartida é ainda minoritária mas parece ir ganhando adeptos, sobretudo no Porto e em Lisboa (Clássica). Mas claro que a opção depende também dos objectos teóricos das cadeiras, uma vez que demarcar as várias etapas da história económica pode não ser bem o mesmo que fazê-lo para a história política ou cultural.

Terceira observação: embora não o tenhamos assinalado expressamente (salvo num caso ou noutro), grande parte dos programas principia com a dilucidação de problemas de natureza teórica e metodológica, o que parece bastante avisado tendo até em conta a fragilidade da formação cultural de base dos alunos que chegam actualmente às Universidades. 
Quarta observação: contrariamente ao que verificámos suceder em Coimbra e no Porto anteriormente ao 25 de Abril de 1974, há hoje um muito maior equilíbrio entre o ensino das matérias alusivas à Alta e à Baixa Idade Média. Ou seja, está-se a valorizar os séculos XI a XV. No entanto, a geografia de base permanece em grande medida semelhante: a França continua a dominar, facto que encontra evidente testemunho na bibliografia sugerida aos alunos ${ }^{25}$, que preserva um fortíssimo pendor francófono (o que, aliás, coloca hoje um problema delicado uma vez que os nossos alunos raramente conseguem ler em língua francesa). Claro que já dispomos hoje de muitas obras francesas traduzidas para português e é isso que mitiga o problema que acabámos de assinalar. Em resultado disto, a bibliografia da maior parte dos cursos é dominada por livros de Georges Duby, Jacques Le Goff, Guy Fourquin ou Henri Pirenne (para citar apenas os casos mais emblemáticos), verdadeiros 'clássicos' pelos quais a maioria dos docentes decerto também aprendeu mas que estão hoje acessíveis na língua mãe dos nossos estudantes.

Quinta observação, ainda relativamente aos temas eleitos e à respectiva geografia. É interessante notar a preocupação de vários docentes em não deixar de fora o Islão e o Império Bizantino nos seus programas. Isso nota-se sobretudo na Faculdade de Letras de Lisboa, onde essa tradição julgamos ser maior (sobretudo no que diz respeito aos Estudos Islâmicos), mas não exclusivamente: também Évora e mesmo a Nova de Lisboa começam a apontar no mesmo sentido. Já o ensino da história da Inglaterra, da Itália e da Alemanha conhecem (salvo raras excepções) dias menos felizes, aparecendo sobretudo nos programas por via de temas bastante específicos ou colaterais (p. ex., o florescimento das cidades italianas, o Sacro-Império Romano-Germânico ou a Guerra dos Cem Anos) e não propriamente como objecto de estudo autónomo e circunstanciado. Quanto ao estudo da Península Ibérica, registámos a sua presença em diversos casos, mas não nos parece tão pertinente retirar daqui ilações uma vez que existem cursos paralelos de História Medieval de Portugal. Por fim, sublinhamos que a temática da Cruzadas se encontra em crescendo, surgindo representada em todas as Universidades. É uma nota positiva, uma vez que se trata - em nosso entender - de um tema poderoso e que, de alguma forma, sintetiza múltiplos aspectos da história do mundo medieval (economia, política, religião, arte militar, relação Ocidente-Oriente, etc.) ao longo de um arco cronológico bastante amplo (no mínimo, de 1097 a 1270).

${ }^{25}$ Devemos notar que algumas faculdades limitam o número de títulos a indicar pelos docentes na bibliografia das respectivas cadeiras. 
Em conclusão, totalmente semestralizado, enquadrado agora no controverso 'sistema de Bolonha', dirigido a alunos com conhecimentos de base ao nível da História e da Geografia muito precários e sem bons hábitos de leitura e de trabalho ${ }^{26}$, o ensino da história medieval europeia nas Universidades vai fazendo o seu percurso com a dignidade possível. É visível o esforço de docentes cada vez mais sobrecarregados com serviço lectivo e administrativo para se adaptar às novas circunstâncias. A observação panorâmica que conduzimos mostra a preocupação dos docentes em diversificar os temas de ensino, em articular os programas com os colegas da mesma área, em tornar acessível aos alunos a bibliografia de base, em utilizar os recursos audiovisuais como forma de apoio às suas aulas e até em multiplicar a oferta de disciplinas de opção que possam de algum modo colmatar as lacunas inevitavelmente abertas por programas muito concentrados e que se destinam a ser cumpridos em semestres que são, na verdade, pouco mais do que trimestres, cada qual com 12 a 15 semanas úteis de aulas. Que este esforço possa pelo menos continuar a atrair alguns (bons) alunos para a zona das pós-graduações em História Medieval, garantindo um futuro digno para a investigação científica nesta área. Seria essa a melhor homenagem que poderíamos prestar aos Mestres da 'Escola de Coimbra' que tivemos o grato prazer de aqui evocar.

Recebido em/Text submitted on: 23/06/2011 Aceite em/Approved on: 29/07/2011

${ }^{26}$ A comparação que faço tem como referência os alunos dos anos 70 e 80 , ou seja, diz respeito aos últimos 30 a 40 anos, período que conheço melhor e por experiência pessoal, primeiro como estudante, depois como docente. Como é sabido, os estudantes actuais dispõem, em contrapartida, de outras capacidades, designadamente de natureza tecnológica, que também podem ser muito úteis no processo de aprendizagem mas que, em nosso entender, não devem fazer esquecer as suas fragilidades ao nível da cultura geral e de algumas competências básicas (como a expressão oral e escrita, a capacidade de síntese ou a destreza na leitura em língua estrangeira). 